\title{
Assessment of the starter motor system use powered by capacitive power sources on internal combustion engine
}

\author{
Anton Bijaev $^{1 *}$ and Kristina Ishutochkina ${ }^{1}$ \\ ${ }^{1}$ Russian State Agrarian University of Moscow Timiryazev Agricultural Academy, 49, \\ Timiryazevskaya st., Moscow, 127550, Russia
}

\begin{abstract}
The main power source of modern electric start systems for internal combustion engines is an acid-lead battery. Existence chemical reactions, which occur in between battery electrolyte and lead plates may be causes problems with it exploitation. For a many reasons, its operation requires a lot of labor, especially in cold conditions. In this regard, it was proposed to use a capacitor system electric supply taking in view its discharge characteristics. Electrolytic capacitors and supercapacitors are sources of temporary charge storage and have optimal properties for their use in the engine start system as a partial displacement of the acid-lead battery, against the background of its some negative qualities. The article deals with the evaluation and comparison of the electric motor start system from capacitors and supercapacitors, as well as the possibility of their implementation on a mobile machine equipped with ICE.
\end{abstract}

In most cases of vehicles such as tractors and automobiles, a starter motor with an electric power source (acid-lead battery) feeding it is used as a starting system for the internal combustion engine. Such a system is controlled via a relay or additional electronics from the ignition switch and has an overall efficiency of $50-70 \%$ [1]. This is primarily due to the flow of high currents, heating of wires, high mechanical moments of resistance in the flywheel drive system, slowing down the flow of chemical reactions occurring in the battery, especially in cold conditions, while operation processes also prevent crankshaft to spin up $[2,3]$. Difficult start-up in cold conditions is a consequence of a decrease chemical process velocity and result the battery capacity, as well as inrush currents, and is a frequent problem in the operation of such systems $[4,5]$.

The size of the existing acid-lead batteries provides sufficient electrical power necessary for the starter motor to work when beginning rotate a crankshaft the internal combustion engine, despite the fact that the other of the electrical equipment of the vehicle does not require such power [6]. Therefore, most part of the battery can be removed and replaced with other electric energy source that have better current supplying and carrying characteristics in various conditions, and size of the battery can be significantly reduced, as well it weight. Such elements of electric energy source can be considered electrolytic capacitors and supercapacitors (special double layer capacitors), which have sufficient energy to operate the

*Corresponding author: author@email.org 
starter motor when spin up flywheel of internal combustion engine [7]. It needed to consider that the parameters of supercapacitors and electrolytic capacitors are different, both with each other and with different types of accumulators (Table 1) [4-8].

Table 1. Parameters of most extended portable electric power source types

\begin{tabular}{|c|c|c|c|c|}
\hline Parameters & $\begin{array}{c}\text { Electrolytic } \\
\text { capacitor }\end{array}$ & Supercapacitor & $\begin{array}{c}\text { acid-lead } \\
\text { battery }\end{array}$ & $\begin{array}{c}\text { lithium-ion battery } \\
\text { (different types) }\end{array}$ \\
\hline $\begin{array}{c}\text { Energy intensity, } \\
\mathrm{W} \cdot \mathrm{h} / \mathrm{kg}\end{array}$ & $0,05-0,2$ & $4-32$ & $25-40$ & $120-280$ \\
\hline $\begin{array}{c}\text { Energy intensity, } \\
\mathrm{kJ} / \mathrm{kg}\end{array}$ & $0,18-0,72$ & $14,4-115,2$ & $90-144$ & $432-864$ \\
\hline Price, USD/kJ & $8,5-66,5$ & $9-40$ & $0,02-0,1$ & $0,06-0,6$ \\
\hline Price, USD/kg & $1,5-48$ & $120-4600$ & $1,8-14$ & $26-520$ \\
\hline $\begin{array}{c}\text { Full discharge } \\
\text { cycles to loss } 20 \% \\
\text { recourse }\end{array}$ & $\begin{array}{c}1000000- \\
5000000\end{array}$ & $100000-500000$ & $500-2000$ & $600-15000$ \\
\hline $\begin{array}{c}\text { Working } \\
\text { temperature, } \mathrm{t}^{\circ} \mathrm{C}\end{array}$ & $-50-105$ & $-40-85$ & $-40-70$ & $-20-65$ \\
\hline $\begin{array}{c}\text { Average charging } \\
\text { period at allowable } \\
\text { current, c }\end{array}$ & $0,1-2,0$ & $5-30$ & $36000-50000$ & $900-1800$ \\
\hline
\end{tabular}

To increase the efficiency of the ICE start-up system, it is necessary to use a power source that will not be so strongly affected by the ambient temperature [9]. Moreover, the problem of high currents may be solved by increasing the voltage of the system, while maintaining the same power. At the optimal source of energy in this situation may be capacitors, which are on a par with supercapacitors have a much higher voltage $[6,10]$, which limits their use in this system. Along with the voltage parameters, capacitors have a higher specific energy cost of 8,5-66,5 USD/kJ, compared to lead batteries of $0,02-0,1 \mathrm{USD} / \mathrm{kJ}$ or lithium-ion batteries of $0,06-0,6 \mathrm{USD} / \mathrm{kJ}$, while the counts of discharge-charging cycles is much higher and is about $1 . . .5$ million, compared to $500 \ldots 2000$ full cycles of the battery. Even with a $30 \%$ discharge of the acid-lead battery, count of cycles increases to only $4000 . .7000$, which is still less than the capacitors, so it justifies their use in the system for start the engine. Except relative high cost, lithium ion batteries have been any problems at on-board vehicle operations and limits in use for low temperature [11].

For efficient operation of the ICE starting system, the electric power going to starter motor should be regulated, for order to capacitors maintaining operating voltage on it [12]. To do this, it is convenient to use pulse-width modulation (PWM), regulated by electronic controller. At the same time, a complete rejection of the presence of a battery does not make sense, since it feeds other elements of the electrical equipment of a vehicle, but due to their small consumption, the battery capacity can be decrease by reducing its weight.

The capacitors can be charged through the same electronic component containing the PWM controller, increasing the voltage from the onboard to $500 \mathrm{~V}$, and discharged to the starter motor system, while maintaining certain operating conditions (Figure 1). In this case, the starter motor must have a higher operating voltage than the usual $12 \mathrm{~V}$.

To determine the characteristics of such a system, it is proposed to choose the voltage of the charged capacitor $\mathrm{UK}=500 \mathrm{~V}$ and the capacitance $\mathrm{CK}=22000 \mathrm{uF}$, and for the electric drive, the operating voltage $U c=220 \mathrm{~V}$ at a power of $P c=1 \mathrm{~kW}$. At the same time, it should be taken into account that the energy of the capacitor depends quadratically on the voltage 
and is determined by the expression: $\mathrm{W}=\mathrm{CU} 2 / 2$, so it is rational to choose capacitors of higher voltage than capacitances with the same parameters [13]. At a voltage of more than $500 \mathrm{~V}$, the price of capacitors per unit of energy begins to rise and, among other things, such a system becomes more dangerous, based on this, a voltage of $500 \mathrm{~V}$ is considered optimal.

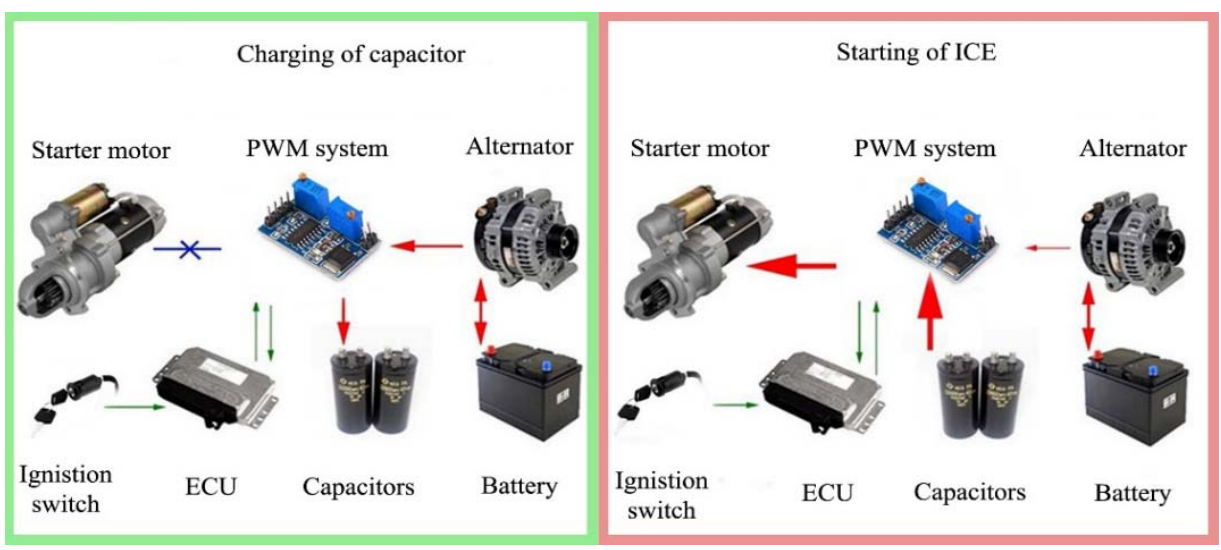

Fig. 1. Scheme of ICE starting system with capacitors supply and PWM control.

The voltage of the electric motor must be less, otherwise when the capacitor is discharged, it will have to be increased, which will require an additional system. In addition, $220 \mathrm{~V}$ is considered a normalized mains voltage that meets the safety requirements and the components of such a motor can be interchanged based on consumer properties. In the calculation, necessity conditionally for first assessment set the constant power of the electric motor $\mathrm{Pc}=\mathrm{W} / \mathrm{t}=$ constant, where $\mathrm{W}$ is the energy received from the capacitor, and $\mathrm{t}$ is the time interval. This is contrary to the real conditions. However, in this work, the task is to compare the indicators of the systems and roughly estimation of the parameters, which will allow assessing the feasibility of the development by approximation results. It should be taken into account that the collector motor has a convenient mechanical characteristic, and increases the torque with an increase in the external load [14].

When the capacitor is discharged without any control system, its voltage will decrease exponentially (Figure 2), while the electrical power will also decrease, at an initially high voltage applied to the starter motor. Conditionally, in this case, the load resistance for the capacitor is constant. In general, the voltage at the starter and the capacitor will be the same and is determined from the physical laws, has the form:

$$
U_{c}=U_{\mathrm{K}} \cdot e^{-\frac{t}{R C_{\mathrm{K}}}},
$$

where $R$ - the resistance of the electric motor circuit, in this case, is conditionally defined as: $R=U_{\kappa}{ }^{2} / P_{c}$.

If this occurs at the beginning of the starter operations, the voltage will exceed the operating voltage, which will lead to a malfunction of the system. To solve this problem, PWM control is used, which maintains the operating voltage on the electric motor (Figure 2 ), at the required power. To express the operating voltage across the capacitors possible as a dependency:

$$
U_{\mathrm{c}}=\sqrt{\frac{2 W}{C_{\mathrm{K}}}}=\sqrt{\frac{2 P_{\mathrm{c}} t}{C_{\mathrm{K}}}} .
$$

PWM control extends the operation of the starter motor at an operating voltage of up to $2.2 \mathrm{~s}$, compared to $0.8 \mathrm{~s}$ without control. This caused by uniform distribution of power over time. 


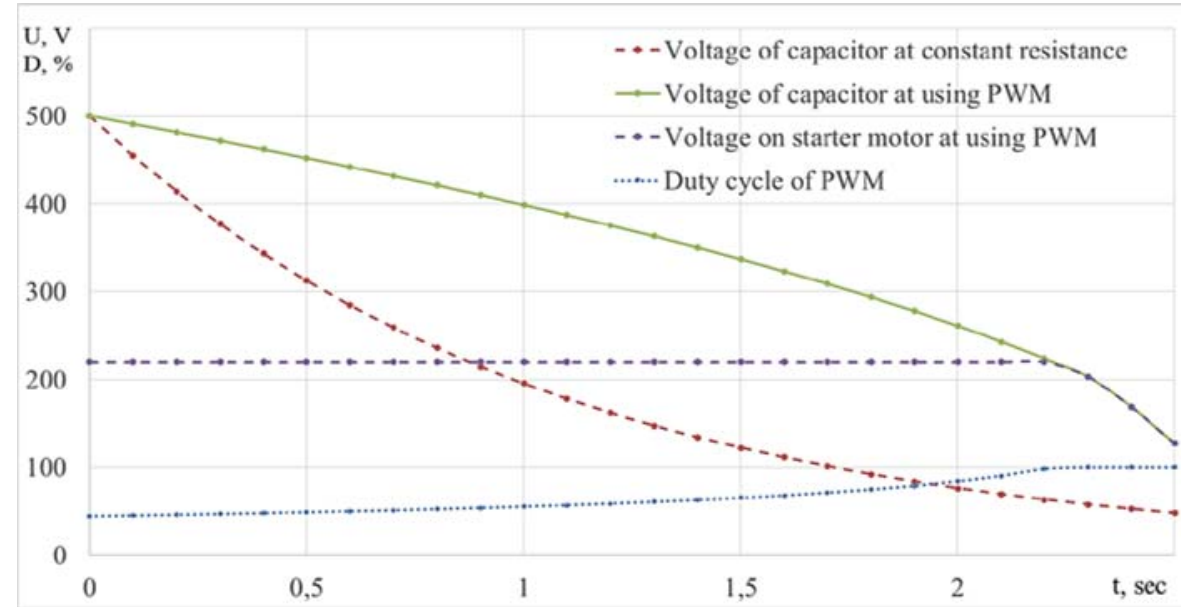

Fig. 2. Voltage on capacitor and starter motor at discharging with and without using PWM system.

The system allows increasing the start-up efficiency due to the increased voltage, since the starting current is reduced, and reduce the size of a lead battery. PWM control allows you to maintain the operating voltage of a starter motor under various operating conditions and ensure a stable start in cold conditions when recharged from the alternator electrical system.

Despite some advantages of high-voltage power systems, they impose many restrictions on the requirements for the safe operation of a vehicle, which makes it difficult to implement them, in addition, it should be known that the on-board system of the machine is low-voltage, which means it will require the use of an additional voltage converter. If to consider semiconductor convertors, that it efficiency at the current level is in the region of $90-95 \%$.

For supercapacitors such converters are not required, since their operating voltage is the same as that of on-board electrical equipment. They only need a system of periodic recharging from the network of the mobile machine without any additional losses [15]. The heating losses of the wiring at high starting currents can be compensated by a closer location of the supercapacitors from the starter motor. At the same time, the heating of supercapacitors from the engine is not so critical, since their maximum operating temperatures are comparably high and are about $85^{\circ} \mathrm{C}$. Besides, supercapacitors have higher energy consumption by there are double layer than that of electrolytic capacitors, their use is more profitable from position of consumer properties [16].

Modern supercapacitors have become more compact and capacious, and with the growth of the technological level over the past 20 years, their volume has decreased by 5-10 times, and their weight by 20-30. For example, the "PCE 28/40" supercapacitor with a volume of 15 liters had a weight of $32 \mathrm{~kg}$, a capacity of $100 \mathrm{~F}$ and a voltage of $28 \mathrm{~V}$, which indicates a maximum stored energy of $39.2 \mathrm{~kJ}$. If we consider a modern supercapacitor such as the "QINFEN HJCAP" with a capacity of $700 \mathrm{~F}$ and a voltage of $2.7 \mathrm{~V}$, its volume is 0.251 , with a weight of $0.5 \mathrm{~kg}$, and has an energy of $2.55 \mathrm{~kJ}$. At an energy level below 15.4 times, it has a weight of 64 times less and a volume of 60 times, which is about 4 times more than the energy change. This opens up another opportunity for consumer use of such systems on automotive equipment.

Based on such supercapacitors a study was conducted on the launch of a 4-cylinder inline gasoline engine with a working volume of 1.6 liters. Engine start up conditions, needed for capacitor choosing, has been defined by mechanic parameters based on math modelling [17]. At the same time, during the start of the engine, the voltage was monitored using an oscilloscope (Figure 3). At the time of starting the internal combustion engine, the electric starter motor was connected to 6 series-connected "QINFEN HJCAP" supercapacitors with 
a capacity of $700 \mathrm{~F}$ and a voltage of $2.7 \mathrm{~V}$ per each. Thus, the total capacity of the supercapacitors battery was $117 \mathrm{~F}$, and the voltage in the charged state was $15 \mathrm{~V}$, which corresponds to the voltage at the output of the alternator when charging the battery. During the experiments, the engine was successfully started from the first time at multiple times, which indicates that the energy capacity of the selected components is sufficient. The starter power of this engine is $2 \mathrm{~kW}$. To increase starter motor operation efficiency may be to add electric control of drive supply system [18].

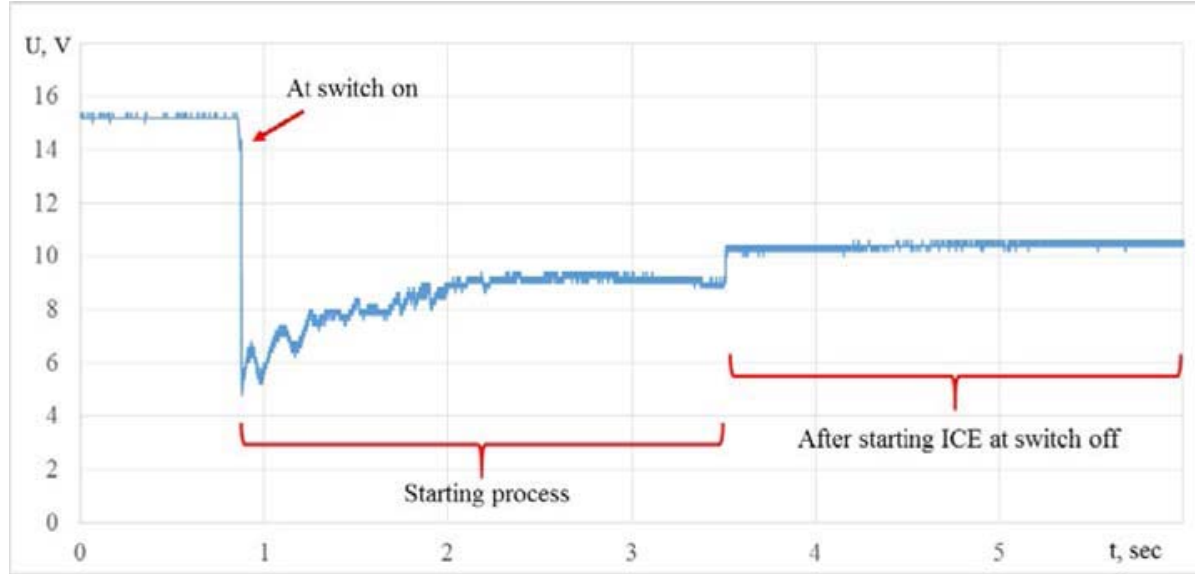

Fig. 3. Changing capacitor voltage at starting.

In practice, automobiles owners to save battery life and make it easier to start the engine in the cold period already use such systems. Nevertheless, the operating conditions of such systems, their parameters and operating data are practically not published anywhere, and there is practically no reliable information in this a knowledge area. In addition, studies on the comparison of the condenser and supercapacitors systems for starting the internal combustion engine were not carried out, but only considered separately, which does not provide complete information on this topic.

Thus, to compare the internal combustion engine start-up systems using supercapacitors and electrolytic capacitors, in addition to comparing the parameters, mathematical modeling of the operation of such systems and experimental research confirming the reliability of the simulation are required.

According to analytical data, it is shown that supercapacitors are more promising electric source in electric motor start systems than electrolytic capacitors, since they have optimal consumer properties. At the same time, their energy is almost 100 times higher than that of electrolytic capacitors at a comparable price in energy equivalent on average 9-40 USD/kJ. Supercapacitors being elements as electrochemical converter, are second only to capacitors in the count of discharge-charging cycles by 10 times and in a narrower temperature range, which is reduced by $10^{\circ} \mathrm{C}$ in the positive and negative directions, which for the most part is not critical for their further use in such systems.

It is experimentally shown that the launch of a 4-cylinder gasoline engine with a working volume of 1.6 liters by means of supercapacitors with a total capacity of $700 \mathrm{~F}$ is possible with power from the on-board network. At the same time, the price of supercapacitors is about the same as that of an acid-lead battery for such an internal combustion engine. All these facts allow us to use supercapacitors in the future as a factory configuration of the vehicle internal combustion engine starting system, since such a system is in many ways superior to an acid-lead battery. 


\section{References}

1. K.A. Ishutochkina, Sistema avtomaticheskogo perezapuska DVS, sbornick studencheskih nauchnyh rabot po materialam dockladov, 72-i Mezhdunarodnoi studencheskoi nauchno-prakticheskoi konferentsii, posvyashchennoi 145-letiyu so dnya rozhdenii A.G. Doyarenko, pp. 111-112. (2019)

2. S.H. Chan, J. Zhu, K.C. Leong, Modelling of engine in-cylinder thermodynamics and exhaust heat transfer at engine cold start, Journal of the Institute of Energy, v. 72(490), pp. 20-31 (1999)

3. A. Plomer, R. Benda, Modern heavy duty diesel engine cold start wear study, Industrial Lubrication and Tribology, v. 52(6), pp. 277-285 (2000)

4. K.A. Ishutochkina, Vybor tipa istochnika elektricheskoi energii s tsel'yu povysheniya effektivnosti zapuska DVS, CHTENIYA AKADEMIKA V. N. BOLTINSKOGO, Sbornik statei seminara, pp. 52-57 (2020)

5. D.A. Khrustalev, Akkumulyatory, Izumrud, p.224 (2003)

6. R.A. Maleev, S.M. Zuev, A.A. Lavrikov, N.P. Grebenchikov, Issledovanie rezhimov raboty emkostnykh nakopitelei energii $v$ sistemakh puska avtomobil'nogo dvigatelya, Izvestiya MGTU "MAMI, v. 1(39), pp. 29-35. (2019)

7. Ivanov S.A., Asadov D.G.O., Bogdanov V.S. Osnovnye napravleniya issledovanii elektrostarternogo puska, p. 60 (2017)

8. A.V. Bizhaev, Otsenka parametrov traktora s elektroprivodnym silovym agregatom, Sel'skokhozyaistvennye mashiny i tekhnologii, v. 14(4), pp. 0-0. (2020)

9. A.V. Zotov, M.A. Sycheva, E.A. Gamoyunov, V.G. Shifrin, Sistema puska dvigatelya vnutrennego sgoraniya s ispol'zovaniem kondensatornogo zapuska, Novye materialy i tekhnologii v mashinostroenii, v. (31), pp. 80-83 (2020)

10. K. Sandra, M. Hosokawa, Electric double layer capacitor, NEC Research and Development, (55), pp. 21-28 (1979)

11. J.-M. Tarascon, M. Armand, Issues and challenges facing rechargeable lithium batteries, Nature, v. 414, pp. 359-367 (2011)

12. M.A. Smirnov, Increasing of start system efficiency in the internal combustion engine using power storages, Aspire to Science, pp. 33-34. (2016)

13. I.E. Rogov, D.S. Belyakov, Otsenka emkosti ionistora $v$ sisteme zapuska dvigatelya vnutrennego sgoraniya, Science Almanac, v. 5-2 (43), pp. 64-67 (2018)

14. A.V. Bizhaev, Problemy vybora tipa privoda silovogo agregata traktora na elektricheskoi tyage, CHTENIYA AKADEMIKA V. N. BOLTINSKOGO, Sbornik statei seminara, pp. 247-252 (2020)

15. S.V. Makarov, M.G. Gurov, M.A. Smirnov, Efficiency upgrading techniques of diesel engine start-up process analysis, Applied Mechanics and Materials, v. 698, pp. 144-149 (2015)

16. A. Despotuli, A. Andreeva, Superkondensatory dlya elektroniki, Sovremennaya elektronika, v. 2(6), p. 46 (2006)

17. N.V. Klinachev, S.G. Voronin, A.I. Sogrin, D.V. Korobatov, N.Yu Kuleva, G.T. Khafizov, A.S. Kul'mukhametova, Modelirovanie protsessa puska dvigatelya vnutrennego sgoraniya elektricheskimi starterom, Vestnik Yuzhno-Ural'skogo gosudarstvennogo universiteta, v. 15(2), pp 49-56. (2015)

18. K. Kroics, Supercapacitors-based engine start battery support device with active control, PCIM Europe Conference Proceedings, pp. 1786-1791 (2018) 